\title{
Pemberian Scaffolding Untuk Siswa Yang Mengalami Kesalahan Dalam Menggambar Grafik Fungsi Kuadrat
}

\author{
Priyati $^{1}$, Helti Lygia Mampouw ${ }^{2}$ \\ ${ }^{1,2}$ Pendidikan Matematika, Universitas Kristen Satya Wacana, helti.mampouw@staff.uksw.edu
}

\section{INFO ARTIKEL}

Riwayat Artikel:

Diterima: 08-03-2018

Disetujui: 24-03-2018

\section{Kata Kunci: \\ Scaffolding \\ Kesalahan konseptual \\ Kesalahan prosedural \\ Fungsi kuadrat}

\begin{abstract}
ABSTRAK
Abstrak: Penelitian ini bertujuan mendeskripsikan pemberian scaffolding dalam membantu siswa menggambar grafik fungsi kuadrat. Subjek adalah IM, RS, dan AM siswa SMA yang sudah belajar tetapi mengalami masalah dalam menggambar grafik fungsi kuadrat. IM cenderung melakukan kesalahan konseptual tentang posisi titik dan operasi bilangan. RS cenderung melakukan kesalahan prosedural dalam menentukan titik koordinat, operasi bilangan dan menggambar grafik fungsi. AM melakukan kesalahan konseptual dan prosedural cukup berimbang tentang koefisien, konstanta, determinan, operasi bilangan, posisi titik dan menggambar grafik. Setelah pemberian scaffolding yang sesuai dengan kesalahannya, ketiga subjek memahami konsep kemudian dapat menggambar grafik fungsi kuadrat dengan benar.
\end{abstract}

\begin{abstract}
This study aims to describe the provision of scaffolding in helping students draw graphs of quadratic functions. Subjects are IM, RS, AM, high school students who have studied but are having problems in drawing the graph of quadratic functions. IM tends to make conceptual mistakes about point position and number operations. $R S$ tends to make procedural errors in determining coordinate points, number operations and drawing function graphs. AM made conceptual and procedural errors quite balanced about the coefficients, constants, determinants, number operations, point positions and drawing graphs. After the appropriate scaffolding of the error, the three subjects understand the concept then can draw the graph of quadratic function correctly.
\end{abstract}

\section{A. LATAR BELAKANG}

Matematika merupakan mata pelajaran yang berkontribusi untuk berkembangnya kemampuan menganalisis pengetahuan faktual, konseptual dan prosedural sesuai bidang kajian yang spesifik dalam matematika. Di SMA, salah satu topik matematika yang harus dikuasai siswa adalah fungsi dan grafiknya. Menurut Permendikbud nomor 24 tahun 2016, kompetensi inti terkait fungsi dan grafiknya adalah kemampuan menjelaskan dan menganalisis karakteristik fungsi kuadrat dan grafiknya. Kemampuan dalam fungsi dan grafiknya penting untuk mendukung penguasaan materi lainnya dalam matematika atau pelajaran lainnya.

Siswa kelas XI IPS 3 SMA N 1 Cepogo Boyolali banyak melakukan kesalahan saat mengerjakan soal yang berkaitan dengan menggambar grafik fungsi kuadrat. Hal ini senada dengan penelitian yang dilakukan oleh Fajar Elmy Nuriyah (2015) kesalahan yang dilakukan siswa kelas X MIA SMA Negeri 2 Wonosari dalam menyelesaikan soal persamaan dan fungsi kuadrat adalah pada penguasaan konsep, penguasaan prinsip, penguasaan ketrampilan perhitungan(1). Hal ini senada dengan penelitian yang dilakukan oleh Wulan Ayu Rahmawati (2014) tentang penalaran siswa dalam menggambar grafik fungsi kuadrat. Hasil penelitiannya menunjukkan bahwa siswa yang menghasilkan gambar grafik fungsi dengan benar mengidentifikasi jenis dan fungsi yang diberikan dahulu lalu mengajukan dugaan. Siswa yang menghasilkan gambar grafik namun salah, ada yang mengidentifikasi jenis dan fungsi yang diberikan dahulu lalu mengajukan dugaan namun ada yang tidak. Siswa yang tidak menghasilkan gambar grafik fungsi ada yang mengidentifikasi jenis dari fungsi yang diberikan dahulu lalu mengajukan dugaan namun ada yang tidak $^{(2)}$.

Rendahnya kemampuan matematika siswa dapat dilihat dari hasil belajar siswa yang masih sering tidak memenuhi harapan. Kesalahan siswa dalam mengerjakan soal atau pemecahan masalah dapat menjadi salah satu petunjuk untuk mengetahui 
sejauh mana siswa menguasai materi. Kesalahan yang dilakukan siswa dapat dibedakan berdasarkan kesalahan konseptual dan kesalahan prosedural. Kesalahan konseptual adalah kesalahan yang dilakukan siswa dalam menafsirkan konsep atau salah dalam menggunakan konsep (Kastolan,1992:6 dalam Sahriah), baik yang terkait langsung ataupun kesalahan pada materi prasyarat. Kesalahan prosedural adalah kesalahan dalam menyusun langkah-langkah yang sistematis dalam menyelesaikan suatu masalah (Kastolan, 1992: 7 dalam Sahriah)(3).

Banyaknya kesalahan yang dilakukan oleh siswa mendorong dibuatnya bantuan dengan berupa dukungan belajar kepada siswa pada tahap awal yang diberikan secara lebih terstruktur, kemudian secara berjenjang menuntut siswa ke arah kemandirian belajar. Pemberian bantuan seperti ini disebut scaffolding (Anghileri:2006). Anghileri (2006) mengungkapkan tiga tingkatan dari scaffolding sebagai serangkaian dukungan dalam pembelajaran matematika. Level paling dasar adalah enviromental provision. Pada level ini siswa didukung untuk belajar mandiri, scaffolding diberikan dengan guru menyiapkan lingkungan belajar siswa yang mendukung (classroom organization) misalkan dengan pengaturan kelompok, menyediakan lembar tugas secara terstruktur (structured task)(4). Scaffolding pada level 1 tersebut ditunjukkan dengan gambar 2.

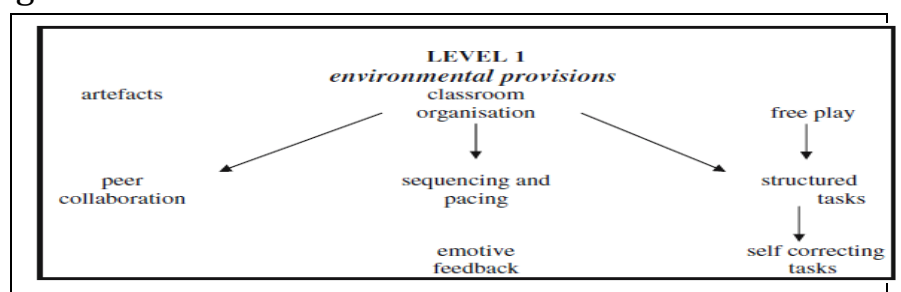

Gambar 1. Scaffolding Level 1

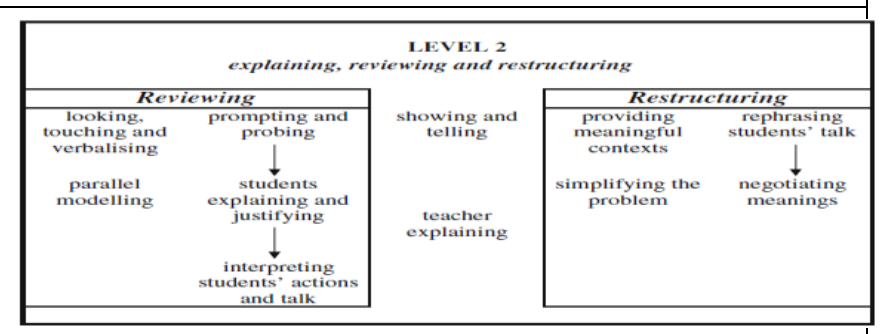

Gambar 2. Scaffolding level 2

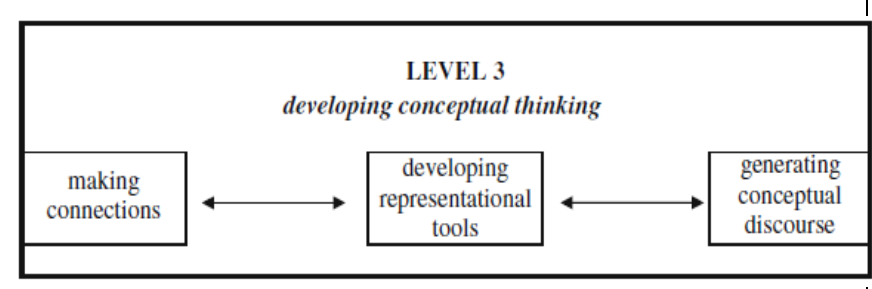

Gambar 3. Scaffolding level 3
Pada level kedua terdapat interaksi langsung antara guru dan siswa. Bentuk interaksi meliputi menjelaskan (expalining) yaitu cara untuk menyampaikan konsep yang dipelajari, meninjau (reviewing) yaitu mengidentifikasi aspek-aspek yang paling penting berkaitan dengan implisit ide-ide matematika atau masalah yang akan dipecahkan, dan restrukturasi (restructuring) yaitu menyederhanakan sesuatu yang abstrak dalam matematika menjadi lebih diterima oleh siswa. Dalam level ini guru dan siswa terlibat secara langsung dalam suatu interaksi, khususnya dalam matematika. Scaffolding pada level 2 tersebut ditunjukkan dengan gambar 2 .

Pada level ketiga menuntut pembelajaran matematika banyak kemampuan untuk mengulang prosedur yang telah dipelajari untuk menyelesaikan maslaah. Tingkat tertinggi dari scaffolding ini terdiri dari interaksi pengajaran yang secara gamblang mengembangkan pemikiran konseptual dengan menciptakan kesempatan untuk mengungkapkan pemahaman kepada siswa. Pada tahap ini siswa didukung untuk membuat koneksi dan mengembangkan alat-alat representasi. Siswa juga dilibatkan dalam wacana konseptual yang dapat meningkatkan daya pikir. Scaffolding pada level 3 tersebut ditunjukkan dengan gambar 3.

\section{B. METODE PENELITIAN}

Jenis penelitian ini adalah deskriptif kualitatif. Penelitian ini dilaksanakan di SMA Negeri 1 Cepogo Boyolali kelas XI IPS 3. Subjek penelitian terdiri dari 3 siswa berkemampuan matematika rendah, sudah mempelajari materi fungsi kuadrat tetapi mempunyai banyak kesalahan dalam proses dan hasil menggambar grafik fungsi kuadrat.

Ketiga subjek dipilih dengan cara sebagai berikut, siswa kelas XI IPS 3 sebanyak 22 siswa , dari 22 siswa tersebut terdapat 5 siswa berkemampuan matematika tinggi, 10 siswa berkemampuan matematika sedang dan 7 siswa berkemampuan matematika rendah. 22 siswa tersebut diberi tes tentang menggambar grafik fungsi kuadrat kemudian dari hasil yang diperoleh dipilih 3 siswa. Hasil tes tentang grafik fungsi kuadrat dari 3 subjek dianalisis dan dipilah berdasarkan kesalahan konseptual dan kesalahan prosedural. Data ini dikuatkan dengan wawancara, berdasarkan kesalahan tersebut dilakukan pemberian bantuan berupa scaffolding.

Scaffolding yang digunakan mengacu pada tahapan scaffolding Anghileri (2006) yaitu Level 1 - 
Enviromental Provision, Level 2 - Explaining, Reviewing, Restructuring, dan Level 3 - Developing Conceptual Thinking(4). Instrumen utama dalam penelitian ini adalah peneliti sendiri dan instrumen pendukungnya adalah dokumen, soal-soal tes dan pedoman wawancara scaffolding. Data yang akan dikumpulkan berupa tulisan dan kata-kata yang menunjukkan kesalahan siswa dalam menggambar grafik fungsi kuadrat. Data diperoleh melalui lembar jawaban siswa yang telah dikerjakan pada saat tes, rekaman wawancara subjek penelitian bersamaan dengan proses scaffolding. Hasil belajar siswa diamati lagi, apabila subjek sudah ada peningkatan dalam belajar maka pemberian scaffolding dianggap berhasil, apabila belum mengalami peningkatan dalam belajar maka dievaluasi kembali proses pemberian scaffolding. Kemudian hasilnya dilaporkan dalam hasil dan pembahasan.

\section{HASIL DAN PEMBAHASAN}

Hasil penelitian berupa pemberian scaffolding bagi siswa dalam menggambar grafik fungsi serta mengatasi kesalahan siswa kelas XI IPS 3 SMA Negeri 1 Cepogo Boyolali dalam menggambar grafik fungsi kuadrat. Presentase kesalahan siswa kelas XI IPS 3 SMA Negeri 1 Cepogo Boyolali dalam menggambar grafik fungsi kuadrat adalah 55,3\% dengan jumlah jawaban salah sebanyak 73. Soal no 4 merupakan soal dengan jawaban salah terbanyak, yaitu sebanyak 17 siswa yang menjawab soal dengan salah. Berdasarkan data tersebut, presentase kesalahan siswa lebih besar daripada presentase jawaban benar dan presentase yang tidak menjawab, sehingga kesalahan-kesalahan yang dilakukan siswa perlu diperbaiki lebih lanjut. Data hasil pekerjaan siswa dikelompokkan menjadi 2 kesalahan yaitu kesalahan konseptual dan kesalahan prosedural.

Berdasarkan hasil penelitian yang dilakukan terhadap siswa kelas XI IPS 3 SMA Negeri 1 Cepogo Boyolali yang berjumlah 22 siswa dengan menggunakan 6 butir soal uraian tentang materi fungsi kuadrat, kesalahan yang paling banyak dilakukan adalah kesalahan prosedural dengan presentase kesalahan sebesar 71,23\%. Kesalahan prosedural memiliki presentase lebih rendah yaitu sebesar 28,77\%. Berdasarkan hasil pekerjaan dari 22 siswa kelas XI IPS 3 SMA Negeri 1 Cepogo Boyolali dipilih 3 subjek penelitian yang akan diberikan scaffolding. Pemilihan 3 siswa sebagai subjek penelitian tersebut berdasarkan kesalahan terbanyak yang dilakukan oleh siswa setelah hasil pekerjaan siswa dikoreksi. Pemberian scaffolding didasarkan pada jenis kesalahan yang dilakukan siswa ketika mengerjakan soal matematika materi fungsi kuadrat. Masing-masing subjek diberikan scaffolding yang berbeda tergantung pada jenis kesalahan yang dilakukan oleh subjek penelitian. Berikut merupakan tabel subjek penelitian

TABEL 1

KESALAHAN KONSEPTUAL

\begin{tabular}{|c|c|c|c|}
\hline \multirow{2}{*}{$\begin{array}{c}\text { Konsep-konsep yang } \\
\text { digunakan untuk } \\
\text { menggambar grafik } \\
\text { fungsi kuadrat }\end{array}$} & \multicolumn{3}{|c|}{ Kesalahan konseptual } \\
\hline & $\begin{array}{l}\text { Subjek } \\
\text { IM }\end{array}$ & $\begin{array}{l}\text { Subjek } \\
\text { RS }\end{array}$ & $\begin{array}{c}\text { Subjek } \\
\text { AM }\end{array}$ \\
\hline 1. Sumbu simetri. & - & & \\
\hline $\begin{array}{l}\text { 2. Koefisien dan } \\
\text { konstanta }\end{array}$ & $3^{*}$ & $3 *$ & $2,3^{*}, 5$ \\
\hline 3. Determinan & $3 *$ & $3 *$ & $1,3^{*}$ \\
\hline $\begin{array}{ll}\text { 4. } & \text { Posisi pada sistem } \\
\text { koordinat kartesius }\end{array}$ & $\begin{array}{c}1,2,3,4 \\
5\end{array}$ & & \\
\hline $\begin{array}{ll}\text { 5. } & \text { operasi pada } \\
\text { bilangan bulat }\end{array}$ & $1,2,4,5$ & & 1,2 \\
\hline 6. grafik fungsi & 4 & & 1 \\
\hline
\end{tabular}

TABEL 2

KESALAHAN PROSEDURAL

\begin{tabular}{|c|c|c|c|}
\hline \multirow{2}{*}{$\begin{array}{c}\text { Konsep-konsep yang } \\
\text { digunakan untuk } \\
\text { menggambar grafik } \\
\text { fungsi kuadrat }\end{array}$} & \multicolumn{3}{|c|}{ Kesalahan konseptual } \\
\hline & $\begin{array}{c}\text { Subjek } \\
\text { IM }\end{array}$ & $\begin{array}{c}\text { Subjek } \\
\text { RS }\end{array}$ & $\begin{array}{c}\text { Subjek } \\
\text { AM }\end{array}$ \\
\hline $\begin{array}{l}\text { 1. Menentukan } \\
\text { persamaan sumbu } \\
\text { simetri }\end{array}$ & & & \\
\hline $\begin{array}{ll}\text { 2. } & \text { Menentukan } \\
\text { koefisien dan } \\
\text { kostanta }\end{array}$ & 2 & 2 & \\
\hline $\begin{array}{l}\text { 3. } \begin{array}{l}\text { Menghitung } \\
\text { determinan }\end{array}\end{array}$ & 2 & 2 & 2 \\
\hline $\begin{array}{l}\text { 4. Menentukan titik } \\
\text { koordinat }\end{array}$ & & $1,5,2$ & \\
\hline $\begin{array}{l}\text { 5. Menghitung operasi } \\
\text { bilangan bulat }\end{array}$ & 3 & $\begin{array}{c}1,2,3,4 \\
5\end{array}$ & 4,3 \\
\hline $\begin{array}{l}\text { 6. Menentukan posisi } \\
\text { titik koordinat }\end{array}$ & 4,5 & 4,5 & 4,5 \\
\hline $\begin{array}{l}\text { 7. Menggambar grafik } \\
\text { fungsi }\end{array}$ & $1,2,3$ & $1,2,4$ & 4,5 \\
\hline
\end{tabular}

1. Pemberian scaffolding pada siswa yang lebih banyak melakukan kesalahan konseptual (subjek IM)

Subjek IM mengalami lebih banyak kesalahan konseptual yang tidak terkait langsung dengan materi fungsi kuadrat, hal tersebut terlihat dari wawancara subjek IM masih belum memahami konsep tentang perkalian bilangan negatif dalam mengerjakan soal fungsi kuadrat tentang menggambar grafik 
fungsi yang memotong sumbu $x$. Bentuk scaffolding yang diberikan pada soal nomor 2 ini berada pada level 2 yaitu reviewing, explaining, dan restructuring.

Scaffolding yang digunakan pada tahap reviewing yaitu melihat kembali jawaban yang telah dituliskan oleh subjek IM untuk mengetahui konsep dasar yang dipahami oleh siswa dalam menggambar grafik fungsi pada soal nomor 2. Peneliti memberikan pertanyaan arahan tentang jawaban siswa serta kebenaran subjek dalam menentukan koefisien dan konstanta serta menghitung Determinnan. Dalam hal ini subjek menjawab bahwa jawaban yang dituliskannya sudah benar, padaha apabila kita lihat pada hasil pekerjaan subjek, subjek belum bisa menentukan koefisien dan konstanta dengan benar sehingga berpengaruh terhadap nilai Determinan. Hal tersebut serupa dengan pertanyaan peneliti tentang kebenaran subjek dalam mencari titik-titik koordinat dengan cara memisalkan nilai $x$, subjek juga menjawab bahwa jawabannya itu benar padahal jawaban yang dituliskannya itu salah.

Scaffolding pada tahap explaining diberikan dengan cara mengingatkan kembali cara menentukan koefisien dan konstanta $(a, b, c)$ pada persamaan yang sudah diketahui, subjek menjawab hasil jawaban yang sudah dituliskannya, lalu peneliti menanyakan lagi kepada subjek "nilai $c$ itu yang bagaimana?". Subjek IM menjawab $c$ itu adalah konstanta, akan tetapi subjek IM tidak menjawab dengan benar nilai konstanta yang dimaksudsetelah diberikan pertanyaan arahan lagi oleh peneliti, subjek baru mengetahui konstanta yang benar. Subjek sudah mengetahui bahwa jika D>0 maka grafiknya memotong sumbu $x$. Setelah menghitung determinan Subjek IM mencari titk koordinat dengan cara memisalkan nilai $x$ nya. Akan tetapi subjek IM melakukan kesalahan pada saat operasi bilangan bulat terutama dalam perkalian bilangan bulat negatif. Hal ini dapat dilihat dari wawancara subjek IM mengatakan bahwa $-3^{2}$ itu hasilnya -9 karena sama-sama ada tanda minus didepannya. Kemudian peneliti menanyakan bagaimana cara perhitungan $3^{2}$ ? Subjek IM menjawab $3 \times 3$, lalu peneliti menanyakan bagaimana dengan yang $-3^{2}$ ? Lalu subjek IM menjawab
$-3 \times 3$, disini peneliti mencari tau lagi "yang dikuadratkan itu -3 atau 3?" Lalu subjek IM menjawab jika yang dikuadratkan itu -3 . Peneliti menanyakan kembali "jika yang dikuadratkan -3 maka cara perhitungannya yang benar bagaimana? Jika yang 3 tadi perhitungannya $3 \times 3$ maka yang -3 berarti?" subjek IM menjawab $-3 \times-3$ hasilnya 9 . Peneliti menanyakan kembali "jika hasil perkaliannya 9 maka hasil perhitungan pada persamaan sebelumnya berapa?" lalu subjek IM menghitung jawabannya ketemu 17 mak titiknya ketemu $(-3,17)$.

Scaffolding tahap restructuring yang diberikan yaitu memberikan pertanyaan arahan sehingga subjek IM dapat menyusun kembali jawabannya. Peneliti mengarahkan subjek IM untuk menghitung lagi apabila nilai $x$ nya $-2,-1,0,1,2,3$, lalu subjek menghitung jawabannya dengan waktu yang cukup lama. Subjek IM menjawab $(-2,7)$, $(-1,1),(0,-1),(1,1),(2,7),(3,17)$. Lalu peneliti meminta subjek IM untuk menggambarkan grafik fungsinya serta menanyakan hasilnya apakah grafiknya memotong sumbu $x$ atau tidak, subjek IM menggambar grafiknya lalu menjawab apabila grafiknya itu memotong sumbu $x$.

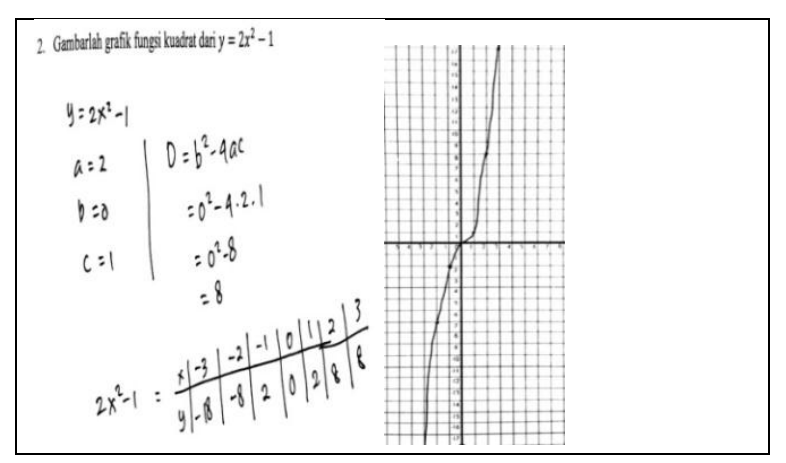

Gambar 4. Contoh kesalahan konseptual pada soal nomor 2 sebelum pemberian scaffolding

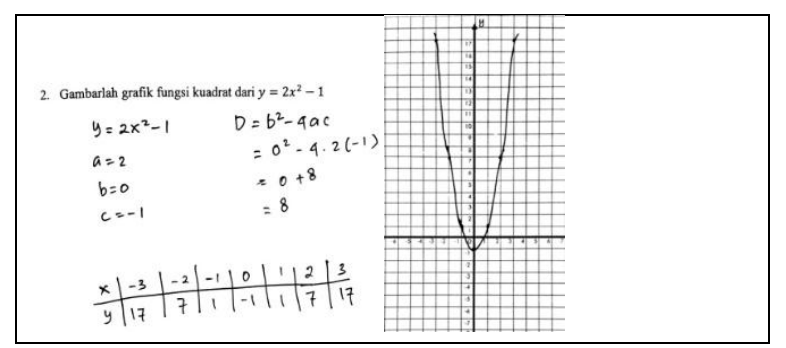

Gambar 5. Contoh kesalahan konseptual pada soal nomor 2 setelah pemberian scaffolding 


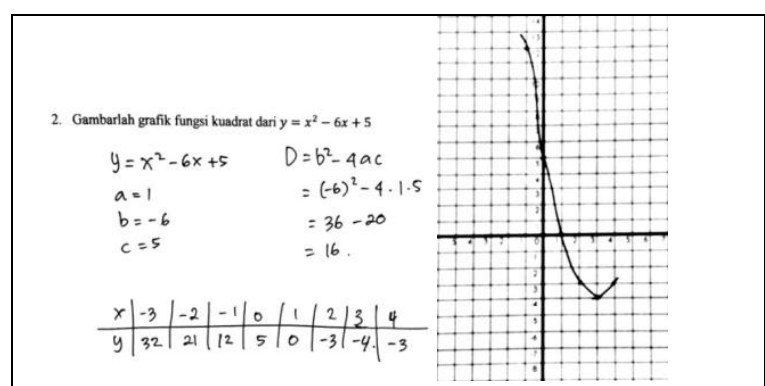

Gambar 6. Hasil pekerjaan soal tambahan

Dengan diberikannya scaffolding pada level 2 yaitu reviewing, explaining dan restructuring kepada subjek IM ternyata dapat membantu subjek IM memahami konsep tentang perkalian dengan bilangan negatif sehingga subjek IM dapat menyelesaikan soal menggambar grafik fungsi kuadrat dengan benar. Sehingga untuk kesalahan konseptual dalam mengerjakan soal menggambar grafik fungsi kuadrat guru dapat memberikan scaffolding pada level 2.

2. Pemberian scaffolding pada siswa yang lebih banyak melakukan kesalahan prosedural (subjek RS)

Subjek RS lebih banyak melakukan prosedural hal tersebut terlihat dari wawancara subjek RS masih belum memahami tentang menentukan titik koordinat, menghitung operasi bilangan bulat, menentukan posisi titik koordinat dan menggambar grafik fungsi kuadrat Bentuk scaffolding yang diberikan pada soal nomor 5 ini berada pada level 2 yaitu reviewing dan restructuring.

Scaffolding tahap reviewing diberikan kepada subjek RS dengan cara menanyakan kembali cara subjek RS dalam menggambar grafik fungsi pada soal nomor 5. Subjek RS menjawab cara menggambar grafik fungsi pada soal nomor 5 yaitu dilihat dulu persamaannya, lalu menentukan koefisien dan konstanta lalu menghitung determinan, setelah menghitung determinan subjek RS mencari titik-titik koordinat untuk bisa menggambarkan grafik fungsi dengan memisalkan $\mathrm{x}$ menjadi $0,1,-1,2,-2$. Dalam hal ini peneliti menemukan bahwa subjek RS mengalami kesalahan saat proses perhitungan dalam memisalkan nilai $\mathrm{x}$, lalu peneliti mengklarifikasi hasil pekerjaan subjek RS menggunakan scaffolding tahap restructuring.
Scaffolding pada tahap restructuring dilakukan dengan peneliti meminta subjek RS untuk meneliti kembali hasil jawaban yang sudah dituliskannya. Lalu subjek RS menghitung kembali hasil jawabannya, ternyata subjek RS menemukan kesalahan saat proses perhitungannya. Subjek RS kurang teliti dalam menghitung nilai $-2^{2}$ sehingga hasil akhir perhitungan subjek RS pun menjadi salah. Setelah menemukan kesalahannya peneliti meminta subjek untuk menggambarkan grafik fungsi dari titik-titik koordinat yang sudah dihitungnya. Disini subjek RS juga salah dalam proses menggambar grafik fungsinya, akan tetapi setelah diarahkan oleh peneliti, subjek RS tahu bahwa cara menghubungkan titik-titik koordinatnya itu keliru.

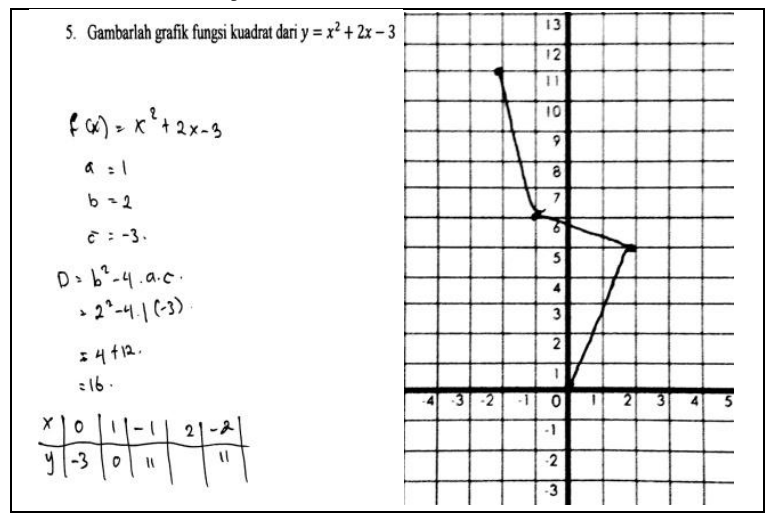

Gambar 7. Contoh kesalahan prosedural pada soal nomor 5 sebelum pemberian scaffolding

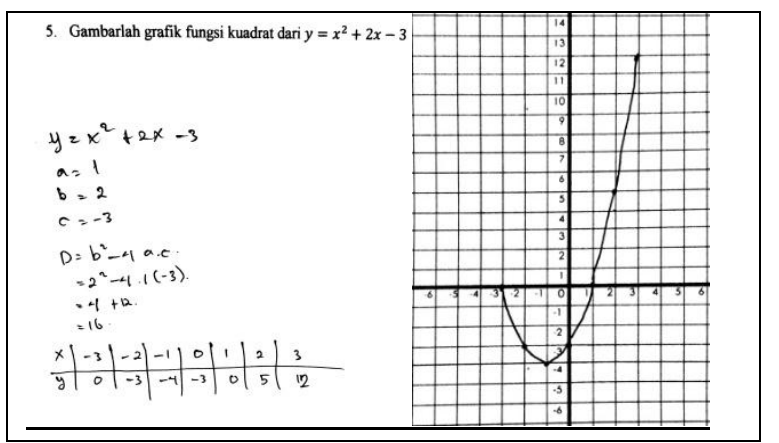

Gambar 8. Contoh kesalahan prosedural pada soal nomor 5 setelah pemberian scaffolding

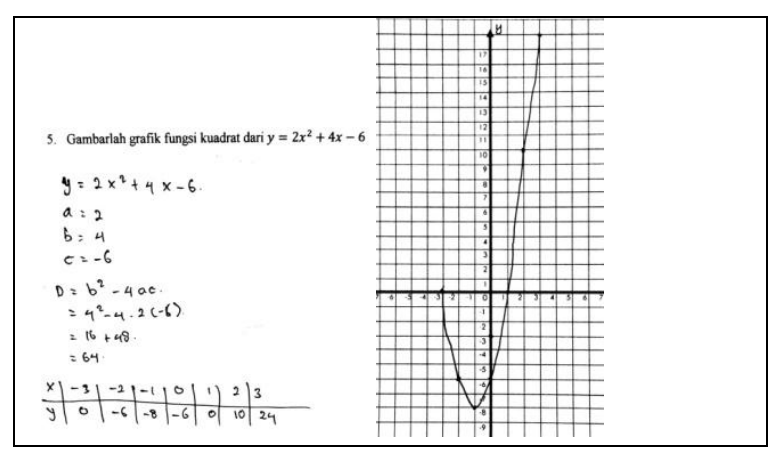

Gambar 9. Hasil pekerjaan soal tambahan 
3. Pemberian scaffolding pada siswa yang mengalami kesalahan konseptual dan kesalahan prosedural berimbang (subjek AM)

Subjek AM lebih melakukan konseptual dan kesalahan prosedural yang relatif berimbang. hal tersebut terlihat dari wawancara subjek AM yaitu tentang koefisien dan konstanta, determinan, operasi bilangan bulat, menentukan posisi titik koordinat dan menggambar grafik fungsi kuadrat. Bentuk scaffolding yang diberikan pada soal nomor 4 dan 1 ini berada pada level 2 yaitu reviewing, explaining dan restructuring.

Subjek AM mengalami kesalahan konseptual yang tidak terkait langsung dengan materi fungsi kuadrat, hal tersebut terlihat dari wawancara subjek AM masih belum memahami konsep tentang perkalian bilangan negatif dalam mengerjakan soal fungsi kuadrat tentang menggambar grafik fungsi yang memotong sumbu $x$. Bentuk scaffolding yang diberikan pada soal nomor 2 ini berada pada level 2 yaitu reviewing, explaining, dan restructuring.

Scaffolding pada tahap reviewing yang diberikan kepada subjek AM yaitu melihat kembali jawaban yang telah subjek AM tuliskan untuk mengetahui langkah-langkah yang digunakan serta aturan penyelesaian yang digunakan oleh subjek AM dalam mengerjakan soal menggambar grafik fungsi kuadrat. Dalam hal ini subjek sudah benar dalam langkahlangkah mengerjakan soal akan tetapi subjek AM salah dalam menggunakan aturan penyelesaiannya. Dapat dilihat dari transkip wawancara dengan subjek AM bahwa dalam memisalkan nilai $x$ untuk mencari titik koordinat subjek tidak menjawab hasilnya dengan benar.

Scaffolding pada tahap explaining peneliti memberikan pertanyaan arahan tentang jawaban yang dituliskan oleh subjek AM. Peneliti meminta subjek AM mengecek kembali hasil jawabannya, sudah benar apa belum jika $x$ nya 1 maka y nya jadi berapa? Lalu subjek menjawab hasilnya 1 karena $1^{2}$ hasilnya 1 . Peneliti menanyakan lagi kepada subjek "jika $x$ sama dengan -1 maka nilai y nya berapa?" Oleh subjek dijawab "hasilnya -1 karena jika $1^{2}$ bernilai 1 maka $-1^{2}$ akan bernilai -1 karena tinggal ditambah - di depannya". Untuk mengetahui penyebab kesalahan yang dilakukan oleh subjek, peneliti memberikan pertanyaan kepada subjek "bagaimana cara menghitung hasil dari $1^{2}$ ?" lalu subjek menjawab $1 \times 1$. Peneliti menanyakan kembali “ jika $-1^{2}$ ?" lalu sambil berpikir subjek menjawab bahwa perhitungannya $-1 \times-1$.

Scaffolding pada tahap restructuring yang diberikan yaitu memberikan pertanyaan arahan sehingga subjek AM dapat menyusun kebali jawabannya. Peneliti menanyakan kepada subjek apabila $x$ nya dimisalkan -2 dan -3 maka hasilnya berapa? Subjek AM menjawab hasilnya 4 dan 9 . Setelah itu peneliti menanyakan dimana saja titik-titik koordinatnya? Sambil menghitung subjek AM menjawab titi-titik koordinatnya berarti di $(-1,1),(-2,4),(-3,9),(0,0),(1,1),(2,4),(3,9)$. Lalu subjek menggambar grafik fungsi kuadrat.

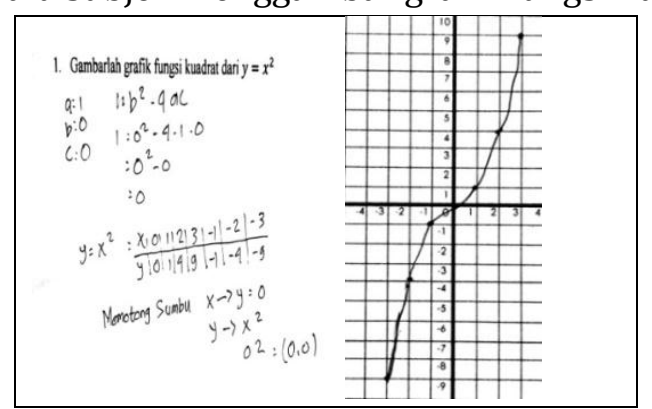

Gambar 10. Contoh kesalahan konseptual pada soal nomor 1 sebelum pemberian scaffolding

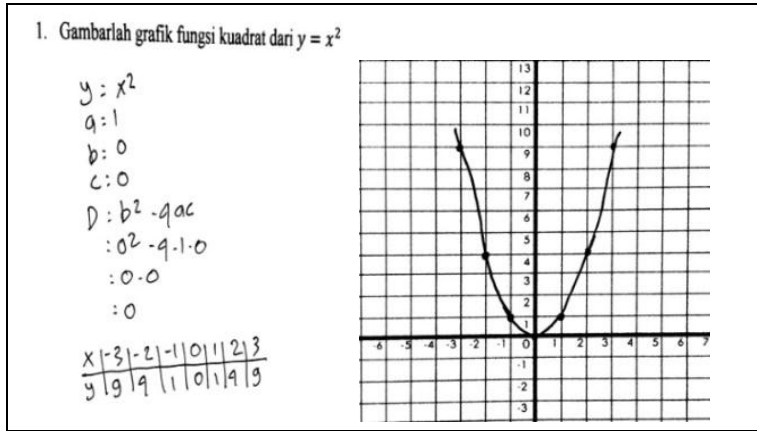

Gambar 11. Contoh kesalahan konseptual pada soal nomor 1 setelah pemberian scaffolding

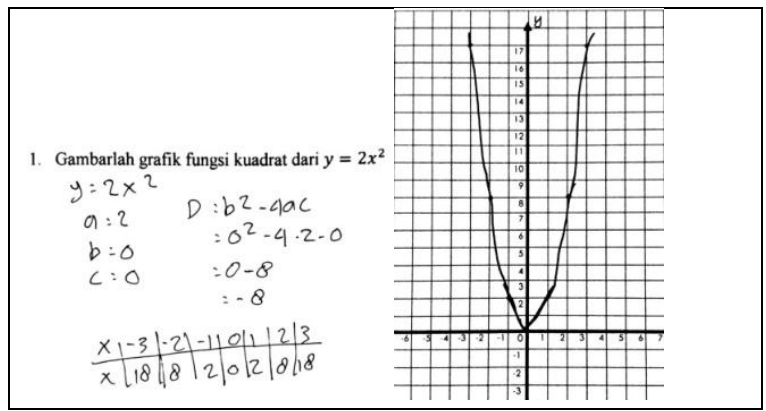

Gambar 12. Hasil pekerjaan soal tambahan 
Hasil pekerjaan subjek AM pada soal nomor 4 pada gambar 8 terlihat bahwa subjek sudah menguasai konsep tentang menggambar grafik fungsi kuadrat, namun pada langkah selanjutnya subjek AM mengalami kesalahan prosedural, terlihat bahwa subjek salah dalam proses perhitungan mencari titik-titik koordinat serta cara subjek AM dalam menghubungkan antar titik-titik koordinat yang sudah diketahui. Scaffolding yang diberikan pada soal nomor 4 ini berada pada level 2 yaitu reviewing dan restructuring.

Peneliti memberikan bantuan berupa scaffolding tingkat reviewing, yaitu dengan menanyakan kepada subjek AM cara menggambar grafik fungsi pada soal nomor 4, lalu subjek AM menjawab cara menggambar grafik fungsi adalah melihat persamaannya lalu mencari nilai $a, b, c$ untuk menghitung Determinannya. Peneliti menanyakan kembali apakah subjek AM sudah benar dalam menghitungnya? Lalu subjek menjawab sudah padahal dari hasil pekerjaan subjek AM masih salah dalam menghitung nilai $y$ nya.

Scaffolding tahap restructuring yang diberikan oleh subjek AM yaitu dengan mengarahkan subjek AM untuk melihat kembali jawaban yang sudah dituliskannya. Peneliti memberikan pertanyaan arahan untuk membantu subjek AM mendapatkan jawaban yang benar. Peneliti menanyakan "kalau $x$ nya 1 nilai $y$ nya jadi berapa?" lalu subjek menjawab "jadinya -2 bu, kan $1^{2}-2(1)+1$ berarti hasilnya $1-2+1$ jadinya 0 , kok ini jadi -2 ya hasilnya (sambil menunjukangka -2)". Peneliti menanyakan kembali jawaban mana yang benar? Subjek AM menjawab yang benar hasilnya adalah 0. kemudian peneliti mengarahkan siswa untuk melihat jawaban subjek AM yang lain, akan tetapi subjek AM masih keliru dalam proses menghitung hasil dari $-1^{2}$ setelah diarahkan oleh peneliti subjek AM baru mengetahui bahwa jawabannya itu keliru. Setelah penyelesaiannya sudah benar peneliti mengarahkan subjek untuk menggambar grafik fungsinya, akan tetapi dalam proses menggambar grafik subjek AM salah dalam proses menghubungkan antara titik koordinat satu dengan titik koordinat yang lain sehingga gambar grafik fungsinya pun salah. Peneliti mengarahkan subjek, bagaimana cara menggambar grafik fungsi yang benar, disini subjek baru mengetahui jika cara menggambar grafik yang dituliskannya tersebut salah.

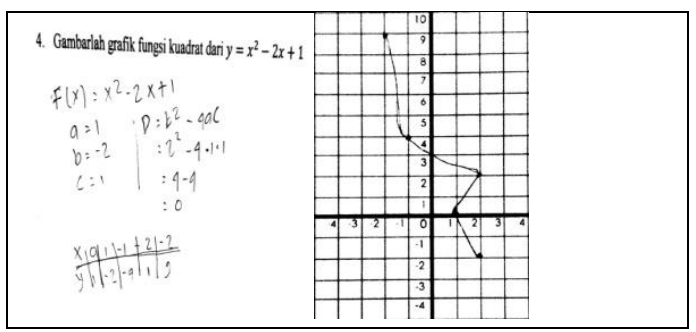

Gambar 13. Contoh kesalahan prosedural pada soal nomor 4 sebelum pemberian scaffolding

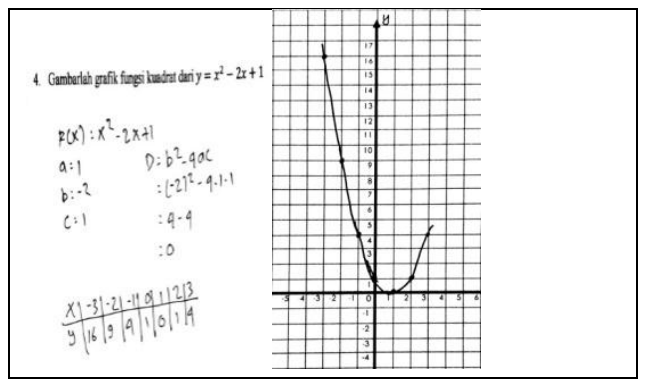

Gambar 14. Contoh kesalahan prosedural pada soal nomor 4 setelah pemberian scaffolding

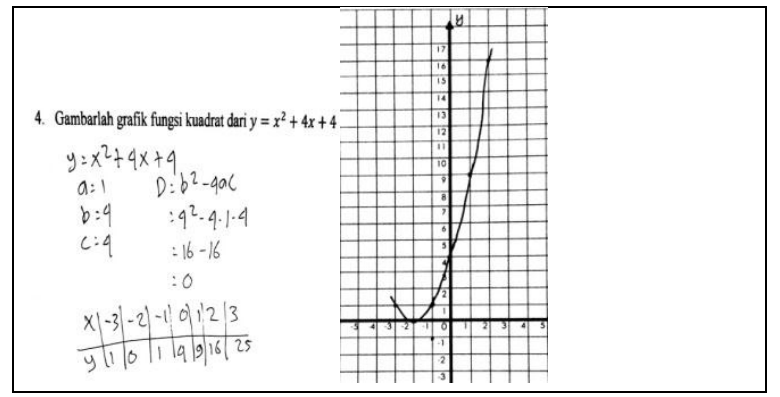

Gambar 15. Hasil pekerjaan soal tambahan

\section{Kesimpulan pemberian Scaffolding pada setiap kesalahan}

Dari data hasil analisis dan pemberian scaffolding yang telah dilakukan oleh peneliti, maka dapat disimpulkan seperti pada tabel berikut:

TABEL 3

PEMBERIAN SCAFFOLDING TIAP TIPE KESALAHAN

\begin{tabular}{l|l}
\hline Tipe Kesalahan & Scaffolding yang diberikan \\
\hline Kesalahan & Tahap reviewing, explaining dan \\
Konseptual & restructuring \\
& Meneliti kembali hasil pekerjaan \\
& (reviewing), membantu subjek \\
& untuk memhami konsep dengan \\
& menjelaskan konsep dengan \\
& benar dexplaining) dan \\
& membangun pemahaman ulang \\
& apabila subjek tidak memahami \\
& konsep (restructuring). \\
\hline
\end{tabular}




\begin{tabular}{l|l}
\hline Kesalahan & Tahap reviewing dan \\
Prosedural & restructuring \\
& Meminta subjek untuk meneliti \\
kembali hasil pekerjaannya \\
(reviewing) dan membangun \\
pemahaman ulang jika subjek \\
tidak memahami konsep \\
(restructuring).
\end{tabular}

\section{TEMUAN ATAU DISKUSI}

Temuan pada subjek IM adalah subjek IM tidak memahami konsep perkalian dengan bilangan negatif dengan benar padahal apabila subjek IM memahami konsep tentang perkalian dengan bilangan negatif dengan benar subjek IM dapat menyelesaikan soal menggambar grafik fungsi kuadrat dengan benar.

Temuan peneliti pada subjek RS adalah Subjek RS sudah memahami materi terkait dengan menggambar grafik fungsi kuadrat, namun subjek AM kurang teliti dalam megerjakan soal sehingga terjadi kesalahan. Kesalahan yang dilakukan subjek RS adalah kesalahan prosedural yaitu pada proses perhitungan serta proses menggambar grafik fungsi yang benar.

Temuan peneliti pada subjek AM adalah Subjek AM sudah memahami materi terkait dengan menggambar grafik fungsi kuadrat, namun subjek AM kurang teliti dalam megerjakan soal sehingga terjadi kesalahan. Kesalahan yang dilakukan subjek AM berimbang antara kesalahan konseptual dan kesalahan prosedural. Pada kesalahan konseptual subjek AM salah memahami konsep tentang perkalian bilangan negatif. Pada kesalahan prosedural subjek AM salah dalam proses perhitungan serta proses menggambar grafik fungsi yang benar.

\section{E. SIMPULAN DAN SARAN}

Berdasarkan hasil penelitian mengenai pemberian scaffolding untuk siswa yang mengalami kesalahan dalam menggambar grafik fungsi kuadrat, kesalahan siswa dibedakan menjadi kesalahan konseptual dan kesalahan prosedural. Kesalahan yang paling banyak dilakukan oleh siswa adalah kesalahan prosedural dengan presentase kesalahan sebesar 71,23\%. Sedangkan kesalahan konseptual memiliki presentase lebih rendah yaitu $28,77 \%$.

Berdasarkan penelitian yang telah dilakukan, subjek IM lebih banyak melakukan kesalahan konseptual terutama tentang posisi titik pada sistem koordinat kartesius, operasi pada bilangan bulat, serta grafik fungsi. Subjek RS lebih banyak melakukan kesalahan prosedural terutama menentukan titik koordinat, menghitung operasi bilangan bulat, menentukan posisi titik koordinat, menggambar grafik fungsi kuadrat. Subjek AM melakukan kesalahan konseptual dan kesalahan prosedural yang relatif berimbang tentang koefisien dan konstanta, determinan, operasi bilangan, posisi titik dan menggambar grafik fungsi kuadrat.

Bentuk scaffolding yang diberikan berada pada level 2. Pada kesalahan konseptual bentuk scaffolding yang diberikan adalah dengan meneliti kembali hasil pekerjaan (reviewing), membantu subjek untuk memhami konsep dengan menjelaskan konsep dengan benar (explaining) dan membangun pemahaman ulang apabila subjek tidak memahami konsep (restructuring). Pada kesalahan prosedural bentuk scaffolding yang diberikan adalah dengan meminta subjek untuk meneliti kembali hasil pekerjaannya (reviewing) dan membangun pemahaman ulang jika subjek tidak memahami konsep (restructuring). Pada kesalahan konseptual dan kesalahan prosedural yang berimbang, bentuk scaffolding yang diberikan sama seperti pemberian scaffolding yang diberikan kepada subjek yang banyak melakukan kesalahan konseptual.

Setelah pemberian scaffolding yang sesuai dengan kesalahannya, ketiga subjek memahami konsep menggambar grafik fungsi kuadrat kemudian dapat menggambar grafik fungsi kuadrat dengan benar. Berdasarkan hasil penelitian ini pemberian scaffolding dapat dilakukan untuk mengatasi kesalahan siswa. Sebaiknya guru melakukan penelusuran kesalahan siswa sebagai upaya untuk memilih scaffolding yang tepat supaya guru dapat membatu siswa mengatasi kesalahan dan meningkatkan hasil belajar siswa.

\section{UCAPAN TERIMA KASIH}

Disampaikan kepada keluarga besar SMA Negeri 1 Cepogo dan Pusat Studi Pendidikan Sains, Teknologi dan Matematika UKSW atas bantuan yang diberikan.

\section{REFERENSI}

[1] Nuriyah, Fajar Elmy. (2015). Analisis Kesalahan Siswa Dalam Menyelesaikan Soal Matematika Materi Pokok Persamaan Dan Fungsi Kuadrat Pada Siswa Kelas X MIA SMA Negeri 2 Wonosari Tahun Ajaran 2014/2015. Skripsi. UKSW Salatiga 
[2] Ayu Rahmawati,Wulan. (2014). Penalaran Siswa Dalam Menggambar Grafik Fungsi. Jurnal Ilmiah Pendidikan Matematika MATHEdunesa. 3(3)

[3] Sahriah, Siti. (2013). Analisis Kesalahan Siswa Dalam Menyelesaikan Soal Matematika Materi Operasi Aljabar Kelas VIII SMP N 2 Malang. SKRIPSI Jurusan Teknik Mesin-Fakultas Teknik UM

[4] Anghileri, J. (2006). Scaffolding Practices That Enhance Mathematics Learning. Journal of Mathematics Teacher Education, 33-52.

[5] Moleong, Lexy.J (2009). Metodologi Penelitian Kualitatif: Bandung: PT. Remaja rosda karya.

[6] Agustina Grahita Handayani. (2014). Identifikasi Kesalahan Siswa Dan Pemberian Scaffolding Dalam Menyelsaikan Soal Matematika Materi Operasi Pecahan Bentuk Aljabar Kelas VII SMP Pangudi Luhur Salatiga. Repositori UKSW

[7] Eka Yoanda, Erindra. (2017). Analsis Pemberian Scaffolding Pada Materi Operasi Hitung Aljabar Bentuk Pecahan Bagi Siswa Kelas VIII SMP. Jurnal pendidikan indonesia, 3(7).

[8] Khanifah, N. M. (2013). Analisis Kesalahan Penyelesaian Soal Prosedural Bentuk Pangkat Bulat Dan Scaffoldingnya. Universitas Negeri Malang.

[9] Manibuy, Ronald, dkk. (2014). Analisis Kesalahan Siswa Dalam Menyelesaikan Soal Persamaan Kuadrat Berdasarkan Taksonomi Solo Pada Kelas X SMA Negeri 1 Plus di Kabupaen Nabire-Papua. Jurnal elektronik pembeajaran matematika, 2(9), 933-945.

[10] Nur A'ini, Siti. (2014). Identifikasi Tingkat Kemampuan Berpikir Kreatif Siswa Dalam Memecahkan Masalah Matematika Materi Fungsi Kuadrat Menggunakan Multiple Solution Task (MST). Jurnal Ilmiah Pendidikan Matematika MATHEdunesa, $3(3)$.

[11] Nur Hanifah, Agustina. (2014). Penggunaan Scaffolding Untuk Mengatasi Kesalahan Siswa Kelas VII H SMP Negeri 2 Mojokerto Dalam Menyelesaikan Soal Cerita Pada Materi Persamaan Linear Satu Variabel. Jurnal Ilmiah Pendidikan Matematika MATHEdunesa, 3(3)

[12] Safitri, Anis. (2017). Profil Pemahaman Siswa Mengenai Konsep Grafik Fungsi Kuadrat Berdasarkan Teori Apos Ditinjau Dari Kemampuan Matematika. Jurnal Ilmiah Pendidikan Matematika MATHEdunesa, 6(2). 